\title{
Isolation and Genetic Identification of Phenol Degrading Bacterium from Wastewater of Assiut University Hospitals
}

\author{
Ahmed Salah ${ }^{1}$, Mohamed Abdel-Wahab ${ }^{1}$ and Abd El-Latif \\ Hesham $^{* 2}$ \\ ${ }^{1}$ Faculty of Sugar and Integrated Industries Technology, Assiut \\ University. \\ ${ }^{2}$ Genetics Department, Faculty of Agriculture, Beni-Suef \\ University, Beni-Suef 62511, Egypt. \\ *Correspondence and reprints: hesham_egypt5@agr.bsu.edu.eg \\ Tel: +2-01012115256.
}

\begin{abstract}
Phenol and phenolic compounds are the most common pollutants in hospital wastewater. Their carcinogenic and toxic effects have been recorded on human being. Identification of the key microorganisms that play a role in pollutant degradation processes is relevant to the development of optimal in situ bioremediation strategies. In the current study, a bacterium strain designated as AUN-AS01 was isolated from wastewater of Assiut University hospitals by enrichment technique in mineral basal salts (MBS) medium supplemented with phenol as a sole carbon and energy source. The strain AUN-AS01 was identified using PCR amplification of $16 \mathrm{~S}$ rRNA gene and sequence analysis. The comparison of the alignment results and phylogenetic analysis of the sequences of the isolated strain to published rRNA gene sequences in Gen Bank, confirmed the identification of the isolate as Paenibacillus mucilaginosus AUN-AS01.The strain was able to grow and had a tolerance of phenol concentration up to $1600 \mathrm{mg} / \mathrm{L}^{-1}$. It was observed that temperature, $\mathrm{pH}$ and initial concentration of phenol play key roles in determining the rate of phenol degradation by the isolated strain AUNAS01. Results showed that, the strain was efficient in removing $92.26 \pm 0.05 \%$ of the initial $800 \mathrm{mg} / \mathrm{l}$ phenol within $48 \mathrm{~h}$ with optimal conditions, at $30{ }^{\circ} \mathrm{C}$ and had a $\mathrm{pH}$ of 7.0. Our results demonstrate that, strain Paenibacillus mucilaginosus AUN-AS01could be used to remove the phenol from the environment. These findings may lead to new
\end{abstract}


biotechnological applications for the degradation of phenol, related to hospitals wastewater.

Keywords: Bacteria; Isolation; Biodegradation; Phenol pollutant; 16S rRNA gene sequencing; Phylogenetic analysis.

\section{Introduction}

Phenol and phenolic compounds are the most common pollutants in hospital wastewater (Arutchelvan, et al., 2007; Mohanty et al., 2017). They have been classified as a highly hazardous chemical (Hooived et al., 1998), and have been included in the list of priority pollutants by the U.S. Environmental Protection Agency (EPA, 1977). It is very important to remove phenol from contaminated water before discharge into any natural water because of their toxicity to aquatic organisms (Sachan et al., 2019). It has severe effect on human being, both short and long term (Sonawane and Koreke 2016).

Phenol removal by biological methods using microorganisms is preferred to physicochemical methods because of its ecofriendliness and cost effective nature and the possibility of complete mineralization of the phenol substrate (Kobayashi and Rittmann, 1982; Thakur, 2004; Prpich and Daugulis, 2005).

Microorganisms produce some enzymes that are effective in treating the industrial effluents containing phenol and its derivatives (Dubey and Hussain 2014). They can utilize phenol as the sole source of carbon and energy (Barbosa et al., 1996). Different microorganisms belonging to bacteria, yeasts, algae and fungi have been reported for their ability to degrade phenol and its derivatives (Sivasubramanian and Namasivayam, 2014).

Therefore, the objectives of this study were: (i) to isolate phenol-degrading bacteria from hospital wastewater, Assiut University; (ii) to identify phenol-degrading bacteria at the species level using polymerase chain reaction (PCR)-based amplification and sequence analysis of the $16 \mathrm{~S}$ rRNA gene; and (iii) to optimize different parameters to enhance the rate of phenol degradation by the isolated bacteria. 


\section{Materials and Methods}

\subsection{Wastewater Sample, isolation and selection of phenol degrading bacteria by enrichment technique:}

For isolation of phenol-degrading bacteria,(Explain: no of samples \& collection method) the sewage wastewater samples were collected from Assiut hospitals area of Assiut University, Assiut. About $5 \mathrm{ml}$ of each sample was suspended in $100 \mathrm{ml}$ of minimal salt medium (MSM) containing $\mathrm{KH}_{2} \mathrm{PO}_{4} 0.5 \mathrm{~g}, \mathrm{~K}_{2} \mathrm{HPO}_{4} 0.5 \mathrm{~g}, \mathrm{CaCl}_{2} 0.1$ $\mathrm{g}, \quad \mathrm{NaCl} 0.2 \mathrm{~g}, \quad \mathrm{MgSO}_{4} \cdot 7 \mathrm{H}_{2} \mathrm{O} 0.5 \mathrm{~g}, \quad \mathrm{MnSO}_{4} .7 \mathrm{H}_{2} \mathrm{O} 0.01 \mathrm{~g}$, $\mathrm{FeSO}_{4} .7 \mathrm{H}_{2} \mathrm{O} 0.01 \mathrm{~g}, \mathrm{NH}_{4} \mathrm{NO}_{3} 1.0 \mathrm{~g}$ per liter double distilled water. $10 \mathrm{mg} / \mathrm{l}$ of phenol was used as sole source of carbon and then incubated in $250 \mathrm{ml}$ flask at $30^{\circ} \mathrm{C}$ on rotary shaking incubator at 120 rpm for a week (Nagamani et al, 2009). A volume of $5 \mathrm{ml}$ of enriched medium was transferred into freshly prepared media on each week supplemented with $10 \mathrm{mg} /$, and then incubated at $30^{\circ} \mathrm{C}$. The final enriched medium were spread on MSM agar plates supplemented with phenol $(500 \mathrm{mg} / \mathrm{l})$. The plates were incubated at $30{ }^{\circ} \mathrm{C}$ and single colonies with morphological differences were selected and they were picked for purification. Pure bacterial isolates were obtained by repetitive streaking on MSM-phenol agarcoated plates and kept on the same MSM slant agar culture at $4{ }^{\circ} \mathrm{C}$.

\subsection{Molecular Identification:}

\subsubsection{DNA Isolation and PCR Amplification of 16S rRNA Gene:}

The genomic DNA from the isolated bacterium was extracted according to the method described by Hesham (2014) and amplified by PCR using $16 \mathrm{~S}$ rRNA universal primers 27F (5AGAGTTTGATCCTGGCTCAG-3) and 1492R (5CGGCTACCTTGTTACGACTT-3) (Lane, 1991). A PCR was performed in 50 $\mu 1$ as a final volume containing GoTaq (Promega, Madison, WI, USA) green master mix, $1 \mu 1$ DNA sample and each primer $1 \mu \mathrm{l}$ (at a concentration of $0.5 \mathrm{mM}$ ). PCR was performed with the following program: 5 -min denaturation at $95{ }^{\circ} \mathrm{C}$, followed by 36 
cycles of 1 -min denaturation at $94{ }^{\circ} \mathrm{C}, 1-\min$ annealing at $55{ }^{\circ} \mathrm{C}$, 1.5-min extension at $72 \circ \mathrm{C}$ and a final extension step of 7 min at 72 ${ }^{\circ} \mathrm{C}$. Five $\mu \mathrm{l}$ of the amplified mixture was then analyzed using $1.5 \%$ $0.5 \times$ TBE agarose gel electrophoresis. The gel was stained with ethidium bromide, visualized under UV light and photographed.

\subsubsection{PCR Products Purification and Sequence Determination:}

To verify the presence of appropriate sized amplicons, the PCR product for The selected was subjected to electrophoresis in $1 \%$ agarose gel according to standard methods. Product of the correct size was purified with a TaKaRa Agarose Gel DNA Purification Kit version 2.0 and sequenced in both directions using an ABI 3730 automated sequencer (Macrogen, Seoul, Korea).

\subsubsection{Comparison of $16 \mathrm{~S}$ rRNA Gene Sequences with GenBank Database:}

The 16S rRNA gene sequences of the selected isolate obtained in this study were aligned and compared with the known 16S rRNA gene sequences in the GenBank database using the basic local alignment search tool (BLAST) at the National Center for Biotechnology Information (http://www. ncbi.nlm.nih.gov/BLAST/) to determine the closest available database sequences.

\subsubsection{Phylogenetic Analysis:}

To determine the taxonomic position of the isolate, a phylogenetic tree was constructed with MEGA version 4.0 using a neighbor-joining algorithm, and the Jukes-Cantor distance estimation method with bootstrap analyses for 1000 replicates was performed (Hesham et al., 2016).

\subsection{Phenol Degradation:}

The culture of strain AUN-AS01 was prepared and adjusted to an optical density at $600 \mathrm{~nm}$ (OD600) of 1.0, then the final concentration of $2 \%(\mathrm{v} / \mathrm{v})$ inoculums were inoculated into the flasks containing MSM medium with phenol as sole carbon source. The 
range of phenol concentrations was increased from 100 to 2500 $\mathrm{mg} / \mathrm{l}$. The flasks were incubated at $30{ }^{\circ} \mathrm{C}$ with $120 \mathrm{rpm}$ for 2 days. Samples were collected to measure the bacterial biomass and the phenol degradation. The biomass contents were monitored spectrophotometrically by measuring absorbance at $600 \mathrm{~nm}$. The phenol concentrations were determined by using 4-aminoantipyrine in the colorimetric assay, according to standard methods reported by the American Public Health Association (APHA, 2005). All experiments were conducted in triplicate.

\subsection{Optimization of culture conditions for phenol biodegradation:}

Factors affecting phenol degradation by the selected bacteria, including $\mathrm{pH}(5-11)$, temperature $\left(20-45^{\circ} \mathrm{C}\right)$ and initial phenol concentration $(100 \mathrm{mg} / \mathrm{L}$ to $2500 \mathrm{mg} / \mathrm{L})$ were investigated. All experiments were conducted in triplicate.

\section{Results and Discussion}

\subsection{Isolation and characterization of phenol tolerating bacteria:}

Several bacterial isolates were isolated from the enrichment cultures of the hospital wastewater samples. Based on its ability to survive the high concentration of phenol, the isolate designated as AUN-AS01was selected for further study. The selected isolate was Gram negative and rod-shaped cells.

\subsection{Identification Using $16 S$ rRNA Gene Sequencing and Phylogenetic Analysis:}

In order to identify and determine the correct phylogenetic position of the selected isolate, molecular genetics identification was performed. In this way, the genomic DNA was extracted from the selected bacterium AUN-AS01 and universal primers $27 \mathrm{~F}$ and $1492 \mathrm{R}$ were used for the amplification and sequencing of the $16 \mathrm{~S}$ rRNA gene fragment. Alignment of 16S rRNA gene sequences of the selected bacterium AUN-AS01 with published 16S rRNA 
sequences from Gen Bank using BLAST shows identity $100 \%$ with Paenibacillus mucilaginous.

\subsubsection{Phylogenetic Tree Analysis:}

Phylogentic tree was constructed for AUN-AS01 strain along with other sequences of the same genus from GenBank to confirm the correct position of the strain. As shown in Fig. 1, strain AUNAS01 and Paenibacillus mucilaginosus share one clade. Therefore, strain AUN-AS01 was identified as Paenibacillus mucilaginosus.

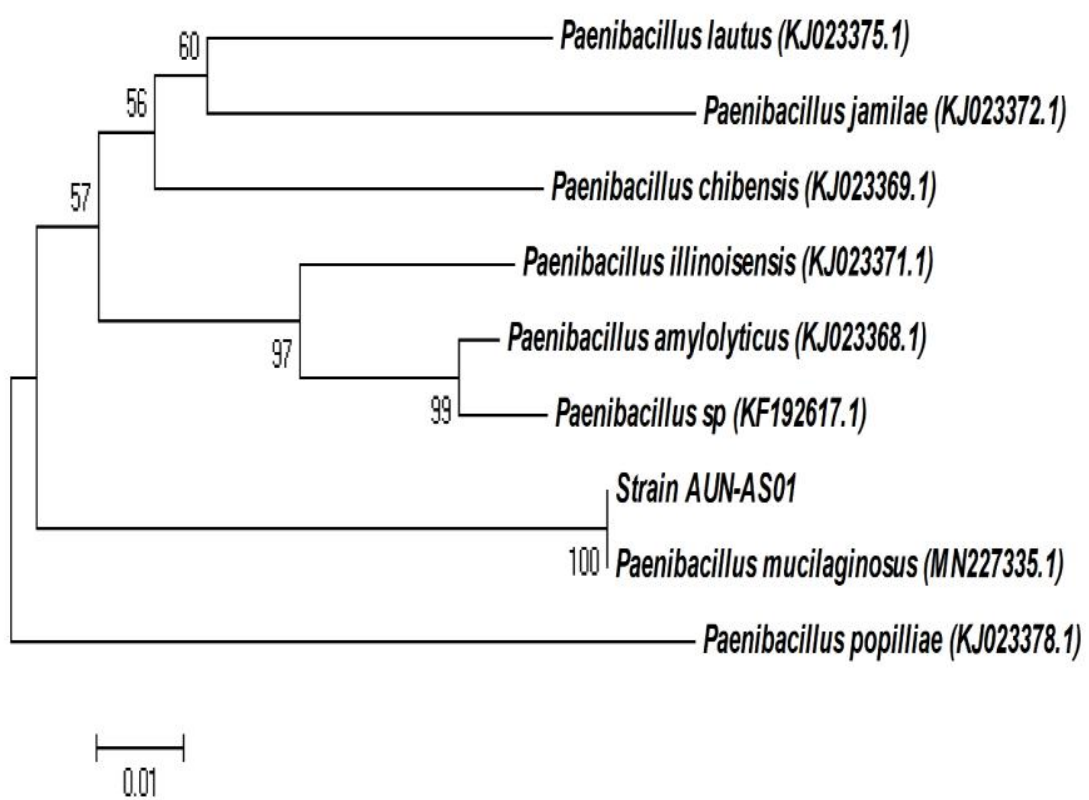

Fig. 1: Phylogenetic tree relationships between strain AUN-AS01 and 16S rDNA sequences from other published Paenibacillus spp. GenBank accession numbers are given in parentheses

Gene comparison studies have shown that 16S rRNA is highly conserved within a species and among species of the same genus (Abd-El-Haleem, et.al., 2002)., identification based on 16S rRNA gene sequencing and phylogenetic analysis was used for the 
bacterial species (Franzetti., 2007; Zhang et al., 2012; Panda et al., 2013; Hesham et al., 2014a, b and Hesham et al., 2016).

\subsection{Phenol Biodegradation by Paenibacillus mucilaginosus AUN-AS01:}

The phenol-degradation rates and biomass of $P$. mucilaginosus AUN-AS01 at various initial concentrations of phenol (200-2500 mg/ $\mathrm{L}^{-1}$ ) were determined by monitoring phenol concentration and cell growth at OD600 at the end of experiment . The degradation of phenol and the biomass growth of $P$. mucilaginosus AUN-AS01 were increased by increasing the phenol initial concentrations. The maximum biomass and the rate of phenol degradation were noticed at the initial phenol concentration of $800 \mathrm{mg} / \mathrm{L}^{-1}$ with the degradation rate of $92.26 \pm 0.05 \%$ (Table 1 ). Results in Table 1 also showed that an inhibitory effect was occurred in the biomass growth and the degradation rate of phenol with the elevated initial phenol concentration higher than $800 \mathrm{mg} / \mathrm{L}$ ${ }^{-1}$, whereas there was no growth of phenol-degrading bacterium when the initial phenol concentration was higher than $1600 \mathrm{mg} / \mathrm{L}^{-1}$.

Many studies on biodegradation of phenol using pure and mixed bacterial strains capable for phenol degradation have been reported by various authors, (Vione et al. 2005; Geng et al. 2006; Stoilova et al. 2006; Chandra et al., 2011; Renard et al., 2016; Suheir et al., 2018). In addition to, Chakraborty et al, (2010) investigated the biodegradation of phenol by native bacteria strains isolated from coke oven processing wastewater. Chandra et al, (2011) reported that phenol is not easily biodegradable and inhibits the innate activity of most of the microbes at higher as well as lower concentrations. This observation is well correlated with our findings. 
Table 1. Biomass of bacterial cell growth (Paenibacillus mucilaginosus AUN-AS01) at $0 D 600$ and rate of phenol degradation at various initial concentrations of phenol from $200-2500 \mathrm{mg} / \mathrm{L}^{-1}$.

\begin{tabular}{|c|c|c|}
\hline \multirow{2}{*}{$\begin{array}{c}\text { Initial phenol } \\
\text { concentrations } \\
\left(200-2500 \mathrm{mg} / \mathrm{l}^{-1}\right)\end{array}$} & \multicolumn{2}{|c|}{ Paenibacillus mucilaginosus AUN-AS01 } \\
\hline & $\begin{array}{l}\text { \% Phenol } \\
\text { removal }\end{array}$ & $\begin{array}{c}\text { Growth rate (Biomass) } \\
\text { OD }_{600}\end{array}$ \\
\hline 100 & $7.31 \pm 0.09$ & $0.24 \pm 0.01$ \\
\hline 200 & $9.11 \pm 0.06$ & $0.37 \pm 0.03$ \\
\hline 300 & $12.23 \pm 0.06$ & $0.47 \pm 0.03$ \\
\hline 400 & $18.78 \pm 0.07$ & $0.54 \pm 0.06$ \\
\hline 500 & $24.26 \pm 0.06$ & $0.63 \pm 0.03$ \\
\hline 600 & $44.18 \pm 0.06$ & $0.70 \pm 0.07$ \\
\hline 700 & $68.20 \pm 0.06$ & $0.84 \pm 0.04$ \\
\hline 800 & $92.26 \pm 0.05$ & $1.04 \pm 0.03$ \\
\hline 900 & $79.32 \pm 0.05$ & $0.91 \pm 0.02$ \\
\hline 1000 & $70.23 \pm 0.06$ & $0.79 \pm 0.01$ \\
\hline 1100 & $60.16 \pm 0.06$ & $0.69 \pm 0.01$ \\
\hline 1200 & $53.71 \pm 0.06$ & $0.62 \pm 0.02$ \\
\hline 1300 & $41.53 \pm 0.04$ & $0.55 \pm 0.03$ \\
\hline 1400 & $32.35 \pm 0.06$ & $0.49 \pm 0.02$ \\
\hline 1500 & $22.19 \pm 0.06$ & $0.42 \pm 0.02$ \\
\hline 1600 & $17.69 \pm 0.06$ & $0.34 \pm 0.02$ \\
\hline 1700 & $11.10 \pm 0.06$ & $0.25 \pm 0.03$ \\
\hline 1800 & $6.35 \pm 0.06$ & $0.24 \pm 0.03$ \\
\hline 2000 & $4.12 \pm 0.06$ & $0.19 \pm 0.02$ \\
\hline 2200 & $2.20 \pm 0.06$ & $0.17 \pm 0.03$ \\
\hline 2500.00 & $1.01 \pm 0.05$ & $0.14 \pm 0.03$ \\
\hline
\end{tabular}

3.4. Effect of $\mathrm{pH}$ and temperature on phenol degradation by Paenibacillus mucilaginosus AUN-AS01

The effects of factors such as $\mathrm{pH}$ values (5-11) and temperatures (20-45) on the degradation of phenol by $P$. mucilaginosus AUN-AS01 were investigated. The bacterial strain could grow within a range of $\mathrm{pH}$ 5-11 (Figure 2). Both acidic and 
alkaline $\mathrm{pH}$ caused a marked inhibition of the phenol removal efficiency. Results also showed that the optimum $\mathrm{pH}$ for phenol degradation was 7.0 with the degradation rate $90.14 \pm 0.07$. Similar phenomena were obtained by Karigar et al. (2006) for Arthrobacter citreus and Mohanty et al., (2017) for Pseudomonas sp.

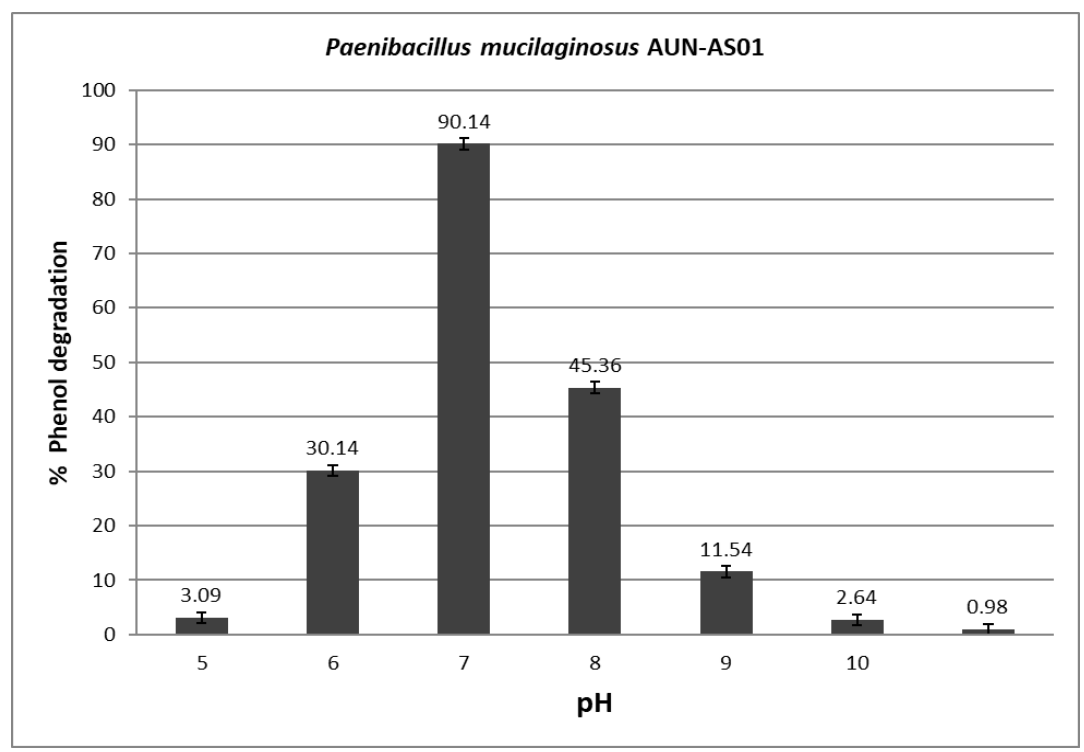

Figure 2: Effect of $\mathrm{pH}$ on phenol biodegradation by the isolate Paenibacillus mucilaginosus AUN-AS01 at initial concentrations of phenol $800 \mathrm{mg} / \mathrm{L}^{-1}$.

\subsection{Effect of Incubation temperature on phenol degradation by Paenibacillus mucilaginosus AUN-AS01}

The results showed that the favored temperature for the bacterial growth of strain AUN-AS01 were ranged from $25-35{ }^{\circ} \mathrm{C}$ (Figure 3) and the maximum degradation of phenol was $93.69 \pm 0.06$ at the temperatures of $30{ }^{\circ} \mathrm{C}$ (Table 3 ). Significant degradation also observed at $25{ }^{\circ} \mathrm{C}(62.32 \pm 0.06)$ and $35^{\circ} \mathrm{C}(52.82 \pm 0.06)$ even if it was less than at $30^{\circ} \mathrm{C}$. In addition to, degradation was inhibited both at low as well as high temperatures. Similar results have been reported on the Pseudomonas pictorum at $30^{\circ} \mathrm{C}$ by Annadurai et al. (2007), Cordova-Rosa et al. (2009); Mohanty et al., (2017) .Our results demonstrated that the strain could grow and remove more 
than $90 \%$ of the phenol at the optimal conditions of $30^{\circ} \mathrm{C}, \mathrm{pH} 7.0$ and the initial concentrations of phenol $800 \mathrm{mg} / \mathrm{L}^{-1}$.

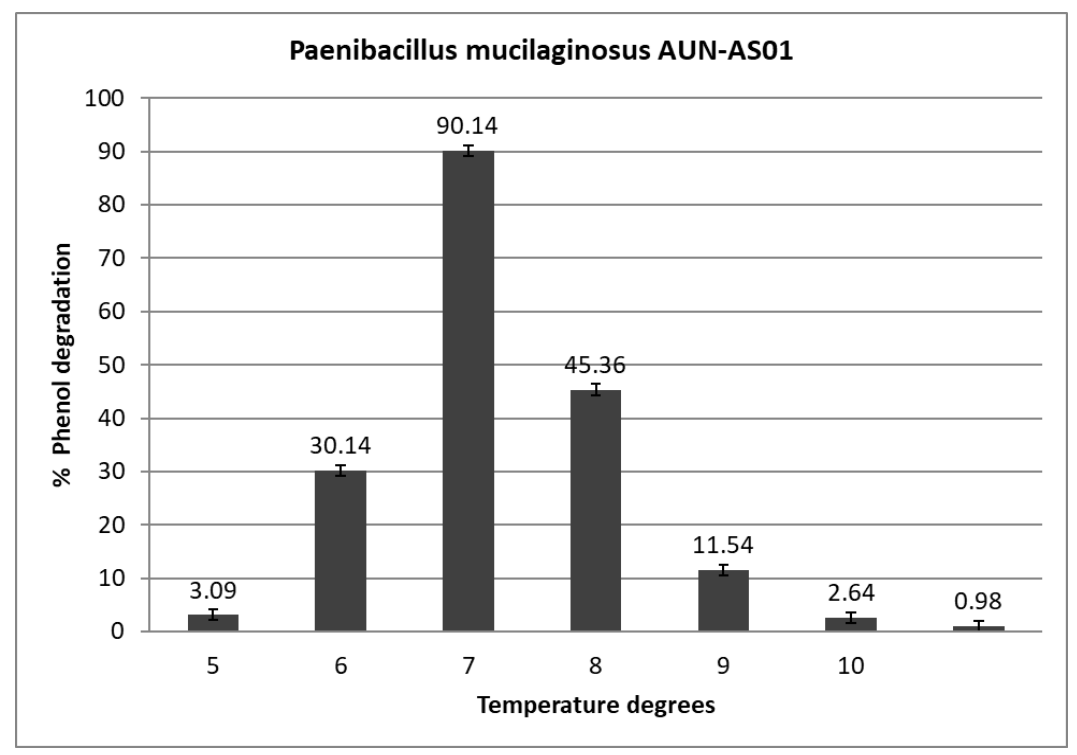

Figure 3: Effect of temperature on phenol biodegradation by the isolate Paenibacillus mucilaginosus AUN-AS01 at initial concentrations of phenol $800 \mathrm{mg} / \mathrm{L}^{-1}$.

\section{Conclusion}

In conclusion, a bacterial strain capable of degrading phenol was isolated from hospital wastewater in Assiut university, Egypt and it was identified based on 16S rRNA gene sequences and the phylogenetic analysis as Paenibacillus mucilaginosus strain AUNAS01. The strain was reported to utilize phenol as the sole source of carbon and energy. Temperature, $\mathrm{pH}$, and initial phenol concentration play key roles in determining the rate of phenol degradation by isolated bacteria. The optimal growth conditions for phenol degradation of the strain were at $30^{\circ} \mathrm{C}, \mathrm{pH} 7.0$. and 800 $\mathrm{mg} / \mathrm{L}^{-1}$ initial phenol concentration that led to rate of phenol degradation above $90 \%$. Our results demonstrate that, strain $P$. mucilaginosus AUN-AS01 could be recommended for phenol removal from hospital wastewater. 


\section{References}

Abd-El-Haleem D, Moawad H, Zaki EA, Zaki S (2002) Molecular characterization of phenol-degrading bacteria isolated from different Egyptian ecosystems. Micro Ecol 43:217-224.

Annadurai, G., Ling, L. Y. and Lee, J (2007) Biodegradation of phenol by Pseudomonas pictorum on immobilized with chitin. Afr J Biotechnol, 6: 296-303.

APHA (2005) Standard methods for the examination of water and wastewater, (20th ed), Washington, New York.

Arutchelvan V, Kanakasabai S, Nagarajan S, Muralikrishnan V (2005) Isolation and identification of novel high strength phenol degrading bacterial strains from phenol formaldehyde resin manufacturing industrial wastewater. J Hazard Mater 127:238-243.

Baruah BK, Baruah D, Das M (1996) Sources and characteristics of paper mill effluent. Environ Ecol 14:686-689.

Chandra R, Yadav S, Bharagava RN. et al. (2011) Phenol degradation by Paenibacillus thiaminolyticus and Bacillus cereus in axenic and mixed conditions, World J Microbiol Biotechnol 27: 2939.

Chakraborty S , T. Bhattacharya T, Patel TN, and Tiwari KK. (2010) Biodegradation of phenol by native microorganisms isolated from coke processing wastewater. $J$ Environm Biol. 31: 293-296.

Cordova-Rosa SM, Dams RI, Cordova-Rosa EV, Radetski MR, Corrêa AXR, Radetski CM (2009) Remediation of phenolcontaminated soil by a bacterial consortium and Acinetobacter calcoaceticus isolated from an industrial wastewater treatment plant. J Hazar Materials. 164: 61-66.

Dubey SK, Hussain A (2014) Phenol biodegradation: a review. Int J Environ Eng 1(2):151-157. 
Environmental Protection Agency (EPA). (1977) Sampling and Analysis Procedure for Screening of Industrial Effluents for Priority Pollutants; EPA: Cincinnati, OH, USA.

Franzetti L, Scarpeluni M (2007) Characterisation of Pseudomonas spp. isolated from foods. Ann Microbiol 57, 39-47.

Geng A, Soh AFW, Lim CJ, Loke LCT (2006) Isolation and characterization of a phenol-degrading bacterium from an industrial activated sludge. Appl Microbiol Biotechnol 72:728735.

Hesham, A.E., Alrumman, S.A. \& Al-Amari, J.A. (2016)16S rDNA Phylogenetic and RAPD-PCR Analyses of Petroleum Polycyclic Aromatic Hydrocarbons-Degrading Bacteria Enriched from Oil-Polluted Soils. Arab J Sci Eng 41, 20952106.

Hesham A. (2014) New safety and rapid method for extraction of genomic DNA from bacteria and yeast strains suitable for PCR amplifications. J Pure Appl Microbiol 8: 383-388.

Hesham A, Asmaa, M M, Yasser M, Shoriet A. ( 2014) Biodegradation ability and catabolic genes of petroleumdegrading Sphingomonas koreensis strain ASU-06 isolated from Egyptian oily soil. BioMed Res. Int. doi.org/10.1155/2014/127674.

Hesham A, Asmaa, M M, Yasser M, Shoriet A. (2014) Study of Enhancement and Inhibition Phenomena and Genes Relating to Degradation of Petroleum Polycyclic Aromatic Hydrocarbons in Isolated Bacteria. Microbiol. 83, 599-607.

Hooived, M.; Heederik, D.J.J.; Kogevinas, M.; Boffetta, P.; Needham, L.L.; Patterson, D.G.; Bueno-de-Mesquita, H.B. (1998),Second follow-up of a dutch cohort occupationally exposed to phenoxy herbicides, chlorophenols, and contaminants. Am. J. Epidemiol. 147, 891-899. 
Kobayashi, H. and Rittmann, B. E., (1982). Microbial removal of hazardous organic compounds. Environmental Science and Technology, 16, 170A-183A.

Lane, D.J. (1991) :16S/23S rRNA sequencing. In: Stackebrandt, E.; Goodfellow, M. (eds.) Nucleic acid Techniques in Bacterial systematics, pp. 115-175. Wiley, New York Mohanty, S.S, and Jena, H.M. Biodegradation Of Phenol By Free And Immobilized Cells Of A Novel Pseudomonas sp. NBM11. Brazilian Journal of Chemical Engineering, 34(1): $75-84,2017$

Nagamani A., Soligala R., Lowry M.(2009) Isolation and characterization of phenol degrading Xanthobacter flavus. African Journal of Biotechnology, 8 (20), 5449-5453.

Panda, S.; Bandyopadhyay, P.K.; Chatterjee, S.N. (2013): Characterization of Pseudomonas aeruginosa PB112 (JN996498) isolated from infected Labeo bata (Hamilton) by 16S rRNA gene sequence analysis and fatty acid methyl ester (FAME) analysis. Afr. J. Biotechnol. 12, 400-405.

Prpich, G. P. and Daugulis, A. J., (2005).Enhanced biodegradation of phenol by a microbial consortiumm in a solid-liquid two phase partitioning bioreactor. Biodegradation, 16, 329-339 .

Renard, P., Canet, I., Sancelme, M., Wirgot, N., Deguillaume, L., and Delort, A.-M. (2016) Screening of cloud microorganisms isolated at the Puy de Dôme (France) station for the production of biosurfactants, Atmos. Chem. Phys., 16, $12347-12358$.

Sachan, P., Madan, S. \& Hussain, A. (2019) Isolation and screening of phenol-degrading bacteria from pulp and paper mill effluent. Appl Water Sci 9, 100

Sonawane BK, Korake SR (2016) Review on removal of phenol from wastewater using low cost adsorbent. Int J Sci Eng Tech $\operatorname{Res}$ 5(6):2249-2253. 
Sivasubramanian $S$ and Namasivayam SKR (2014) Phenol degradation using Candida tropicalis SSK01 isolated from petroleum contaminated soil under optimized medium. J. Pure Appl. Microbiol. 8(1): 641-650.

Stoilova IA, Krastanov SV, Daniel D, Gerginova M, Alexieva Z (2006) Biodegradation of high amounts of phenol, catechol, 2, 4-dichlorophenol and 2, 6-dimethoxyphenol by Aspergillus awamori cells. Enzym Microbiol Tech 39:1036-1041.

Suheir I. Ereqat, Ahmad A. Abdelkader, Abedelmajeed F. Nasereddin, Amer O. Al-Jawabreh, Taher M. Zaid, Ilya Letnik \& Ziad A. Abdeen (2018) Isolation and characterization of phenol degrading bacterium strain Bacillus thuringiensis $\mathbf{J} 20$ from olive waste in Palestine, Journal of Environmental Science and Health, Part A, 53:1, 39-45.

Thakur IS (2004) Screening and identification of microbial strains for removal of colour and absorbable organic halogens in pulp and paper mill effluent. Process Biochem 39:1693-1699.

Vione D, Minero C, Maurino V, Carlotti ME, Picatonotto T, Pelizzetti E (2005) Degradation of phenol and benzoic acid in the presence of a $\mathrm{TiO} 2$-based heterogeneous photocatalyst. Appl Catal B: Environ 58:79-88.

Zhang, M.; Liu, W.; Nie, X.; Li, C.; Gu, J.; Zhang, C. (2012): Molecular analysis of bacterial communities in biofilms of a drinking water clearwell. Microbes Environ. 27, 443-448.

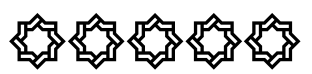




\section{المانغم العربيو}

العزل والتعرف الوراثي للبكتيريا الملالة للفينول الموجود بمياه الصرف الصحي بمستشفيات جامعة أسيوط

أحمد صلاح' - - همد همهود عبدالوهاب1 - عبداللطيف هشام 2

I كلية تكنولوجيا صناعة السكر والصناعات التكاهيلية - جاهعة أسيوط

2 قسم الموراثة - كلية زراعة - جاهعة بنسي سويف

يعتبر الفينول و مشتقاته من أكثر الملوثات شيوعًا في مياه الصرف

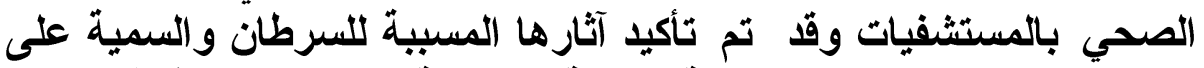

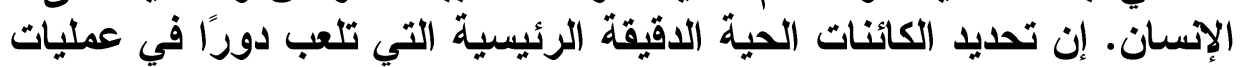

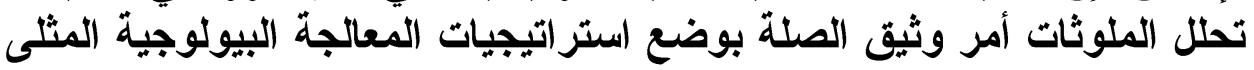

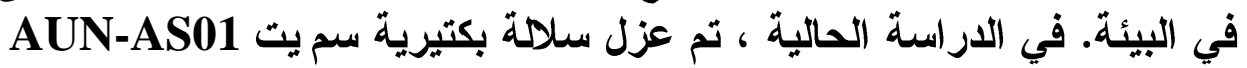

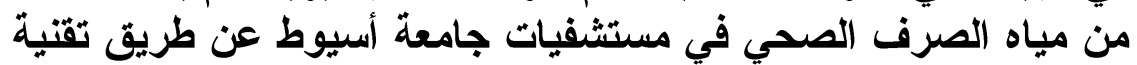

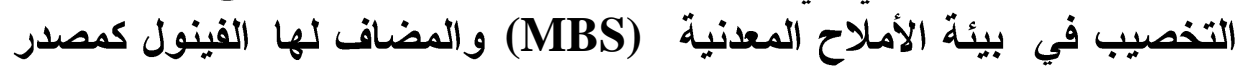

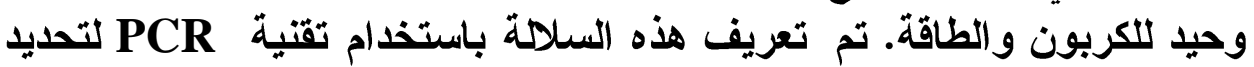

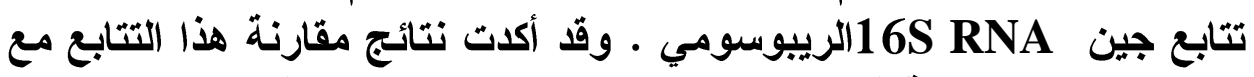

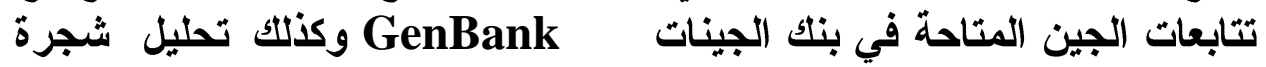

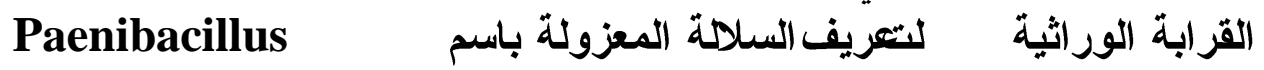

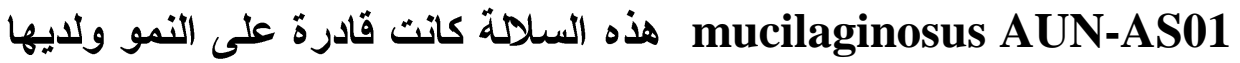

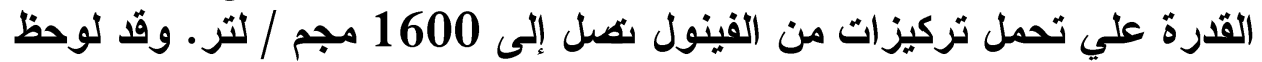

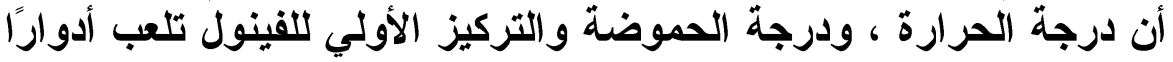

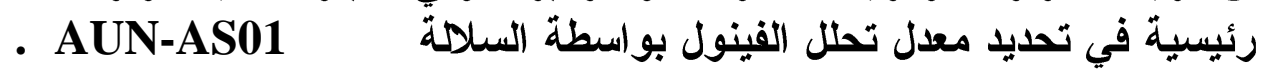

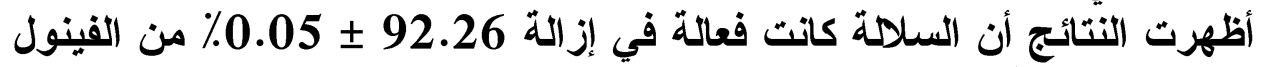

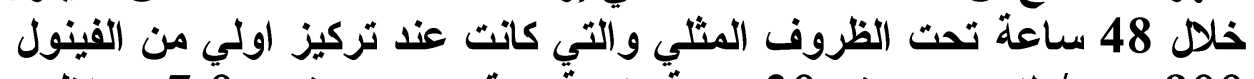

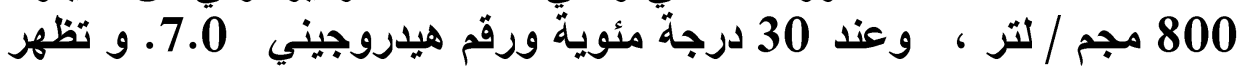

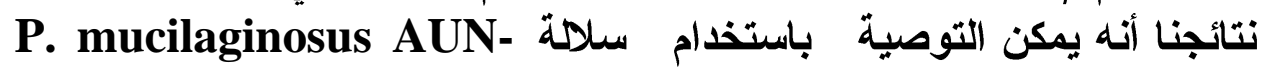
AS01 لإز الة الفينول من مياه الصرف الصحي في المستثف يلت كمعالجة

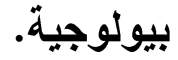

